\title{
IMMIGRATION AND THE WELFARE STATE: IMMIGRANT PARTICIPATION IN MEANS-TESTED ENTITLEMENT PROGRAMS
}

George J. Borjas

Lynette Hilton

Working Paper 5372

\author{
NATIONAL BUREAU OF ECONOMIC RESEARCH \\ 1050 Massachusetts Avenue \\ Cambridge, MA 02138 \\ December 1995
}

We are grateful to Daniel Hamermesh, Lawrence Katz, Glenn Sueyoshi, and Stephen Trejo for helpful comments. This research was supported by a grant from the National Science Foundation. This paper is part of NBER's research program in Labor Studies. Any opinions expressed are those of the authors and not those of the National Bureau of Economic Research.

() 1995 by George J. Borjas and Lynette Hilton. All rights reserved. Short sections of text, not to exceed two paragraphs, may be quoted without explicit permission provided that full credit, including (c) notice, is given to the source. 


\title{
IMMIGRATION AND THE WELFARE \\ STATE: IMMIGRANT PARTICIPATION IN \\ MEANS-TESTED ENTITLEMENT PROGRAMS
}

\begin{abstract}
This paper documents the extent to which immigrants participate in the many programs that make up the welfare state. The immigrant-native difference in the probability of receiving cash benefits is small, but the gap widens once other programs are included in the analysis: 21 percent of immigrant households receive some type of assistance, as compared to only 14 percent of native households. The types of benefits received by earlier immigrants influence the types of benefits received by newly arrived immigrants. Hence there might be ethnic networks which transmit information about the availability of particular benefits to new immigrants.
\end{abstract}

George J. Borjas

Kennedy School of Government

Harvard University

79 John F. Kennedy Street

Cambridge, MA 02138

and NBER
Lynette Hilton

Barents Group, LLC

2001 M Street, NW

Washington, DC 20036 


\section{IMMIGRATION AND THE WELFARE STATE: \\ IMMIGRANT PARTICIPATION IN MEANS-TESTED ENTITLEMENT PROGRAMS}

\section{George J. Borjas and Lynette Hilton}

\section{Introduction}

The historical debate over immigration policy in the United States has focused primarily on two questions: How well do immigrants adjust to their new surroundings? And do immigrants "take jobs away" from native workers? The growth of the welfare state in the past thirty years, as well as the perception that immigrant participation in welfare programs is on the rise, has added an explosive new question to this debate: Do immigrants pay their way in the welfare state? In fact, the concern over the impact of immigration on the costs of welfare programs has led Congress to seriously consider the possibility of denying all means-tested assistance to all non-citizens, regardless of whether they entered the country legally.

The available empirical evidence suggests that an increasing number of immigrants are beneficiaries of welfare programs [Blau 1984; Jensen 1988; Borjas and Trejo 1991; and Borjas 1995]. For the most part, this inference is drawn from the analysis of decennial Census data. ${ }^{1}$ Since 1970, the Census reports whether households receive cash benefits, such as Aid to Families with Dependent Children (AFDC) or Supplemental Security Income (SSI). In 1970, immigrant households were slightly less likely than native households to receive cash benefits. By 1990 , however, the typical immigrant household had a higher probability of receiving cash benefits. In particular, 9.1 percent of the immigrant households enumerated in the 1990 Census received public assistance, as compared to only 7.4 percent of native households.

1 The increase in immigrant welfare recipiency is also confirmed by administrative data [U.S. General Accounting Office 1995]. 
Although this trend has raised concerns over the impact of current immigration policy, the immigrant-native participation rate gap in cash benefit programs is not numerically large. The Census, however, does not provide any information on noncash transfers, such as Food Stamps, Medicaid, and housing subsidies, so that we do not know the extent to which immigrants participate in these other (and more expensive) components of the welfare state. Moreover, the Census reports only if a household received cash benefits during a given calendar year. Hence we do not know if the higher immigrant recipiency rates result from a higher incidence of going on welfare or from longer spells. This is an important distinction because the policy implications of having a dependent immigrant population (where many immigrants are on long-term welfare spells) differ substantially from the implications of having an immigrant stock with a high probability of being in short-term welfare spells.

This paper uses data drawn from the Survey of Income and Program Participation (SIPP) to provide a more complete picture of immigrant participation in the wide array of means-tested entitlement programs that make up the modern welfare state. The SIPP files have the distinct advantage that they contain extensive information on the household's participation in many entitlement programs. The evidence reported in this paper has three potentially important implications. First, the existing literature (with its focus on cash benefits) gives a misleading picture of the extent to which immigrants receive benefits. Although the immigrant-native difference in the probability of receiving cash benefits is numerically small, the "welfare gap" is much larger when other programs are included in the analysis. In the early 1990s, 20.7 percent of immigrant households received either cash benefits, Medicaid, vouchers (mainly food stamps), or housing subsidies, as compared to 14.1 percent of native households (and 10.5 percent of white 
non-Hispanic native households). Second, immigrant households experience both more and longer welfare spells. Immigrant households, therefore, spend a relatively large fraction of their time participating in some means-tested program. Finally, the types of welfare benefits received by earlier immigrant waves influence the types of benefits received by newly arrived immigrants. Hence there might be networks operating within ethnic communities which transmit information about the availability of particular types of benefits to new arrivals.

\section{Data and Basic Trends}

This study uses data from the 1984, 1985, 1990, and 1991 panels of the Survey of Income and Program Participation. The SIPP is a panel survey which collects monthly data by interviewing the same individuals every four months. During the interview, each respondent is asked about his or her economic experiences during the prior four-month period, including benefits received from a large number of means-tested entitlement programs. In the SIPP panels used in this study, the households were reinterviewed at four-month intervals for eight waves, providing us with 32 monthly observations for each household. ${ }^{2}$

The SIPP also reports where each respondent was born, and if born abroad, the year of arrival to the United States. We use this information to classify persons as either natives or immigrants. A person is an immigrant if he or she was born abroad, and is either a naturalized citizen of the United States or is not a citizen. All other persons are classified as natives.

2 The intervening SIPP panels between 1985 and 1990 follow the household for shorter periods. It is well known that the SIPP data exhibits a "seaming" problem [Singh, Weidman, and Shapiro 1989]. In particular, welfare spells tend to begin at the start of each 4-month interview cycle and end at the close of the cycle. The analysis presented in this paper ignores the possible biases created by this problem. 
The SIPP collects information on all persons in the household. One of these persons is called the "reference person" or "householder." The householder is the person who either owns the house or whose name it is rented under. If the house is owned jointly by a married couple, either the husband or wife may be listed as the reference person. We restrict our analysis to the sample of persons who are householders in the first month of the panel (effectively making the household the unit of analysis), and we then follow the household's welfare participation history over the course of the 32-month sample period.

The 1984 panel collected the immigration information in the 8th and final wave (so that no immigration information is available for householders who left the survey prior to its conclusion). To maintain comparability across the panels, we restrict our analysis to households that were interviewed throughout the entire 32 -month sample period. This sample restriction generates potential biases due both to sample attrition and to the creation of "split-off" households (i.e., households formed when a person separated from the original household unit). We show below that these biases do not alter our conclusions. Finally, we restrict our study to householders who were at least 15 years old. A household will be considered to be an immigrant household if the householder is an immigrant; otherwise the household will be considered to be a native household.

Table I lists the main welfare programs that we will study in this paper, the types of benefits provided by the programs, and the cost of each of the programs. ${ }^{3}$ In 1991, the total cost of these means-tested entitlement programs (at all levels of government) exceeded $\$ 180$ billion. Cash benefit programs account for less than a quarter of the cost of these means-tested programs.

\footnotetext{
${ }^{3}$ A description of these means-tested programs is given in U.S. House of Representatives [1992]. The main means-tested program not covered by our analysis is the Earned Income Tax Credit.
} 
The SIPP files contain information on whether any person in the household participated in any of these (and other) programs. We initially pool the data in the 1984 and 1985 panels across householders and months, and calculate the probability that a household participated in each of the various programs during a typical month in the mid-1980s. Similarly, we pool the data in the 1990 and 1991 panels, and calculate the probability that a household participated in the various programs in the early 1990 s. $^{4}$

Table II shows that immigrant households are more likely to participate in practically every one of the major means-tested programs. In 1990/1991, the typical immigrant household had a 4.4 percent probability of receiving benefits from the AFDC program, as compared to only 2.9 percent for native households. Similarly, over 9 percent of immigrant households received food stamps, as opposed to only 6.5 percent of native households. Finally, 15.4 percent of immigrant households were covered by Medicaid, as compared to only 9.4 percent of native households.

The data also reveal that the immigrant-native welfare gap rose rapidly during the last half of the 1980s. In the mid-1980s, 8.4 percent of native households received Medicaid, as compared to 11.0 percent of immigrant households, a gap of 2.6 percentage points. By the early 1990 s, the gap in Medicaid participation rates widened to 6.0 percentage points.

Finally, the data suggest that earlier studies-(which focused on cash benefits) understated the extent to which immigrant households benefit from welfare programs. To measure the "true" incidence, we use five increasingly broader measures of welfare benefits: (1) participation in any

\footnotetext{
${ }^{4}$ The results reported in this paper use the SIPP sampling weights. The methodology used to calculate these weights changed during the course of the 1991 panel to incorporate information provided by the 1990 Census. We assign the weight associated with the householder in the first month of each panel to all 32 months of the panel. The results are not affected by this procedure.
} 
cash benefit program5; (2) participation in cash benefit programs or Medicaid; (3) participation in cash benefit programs, Medicaid, or voucher programs (voucher programs include food stamps, WIC, and energy subsidies); (4) participation in cash benefit programs, Medicaid, voucher programs, or housing subsidies; and (5) participation in cash benefit programs, Medicaid, voucher programs, housing subsidies, or the National Breakfast and Lunch School Program. The bottom panel of Table II report the participation rates in these measures of public assistance.

If we restrict our attention to cash benefits, immigrants are more likely to receive welfare, but not by much. The immigrant-native difference in participation rates is 3.5 percentage points. ${ }^{6}$ When we expand our definition of welfare to include Medicaid, voucher programs, and housing assistance, the immigrant-native gap widens to 6.6 percentage points. In fact, nearly 21 percent of immigrant households received at least one of these benefits during the typical month. ${ }^{7}$

The data reported in Table II uses the household as the unit of analysis partly because the benefits received in some welfare programs (particularly those related to housing subsidies) are reported only at the household level, and also because the data on immigration status exist only for persons aged 15 or over. ${ }^{8}$ Using the household as the unit of analysis, however, introduces

${ }^{5}$ Although Table II only reports participation rates for AFDC, SSI, and General Assistance, the SIPP files contain information on the total amount received from cash benefit programs.

${ }^{6}$ These probabilities of receiving cash benefits can be compared to the Census figures. The 1990 Census reports that 7.4 percent of native and 9.1 percent of immigrant households received benefits in 1989 . If we use the 1990 SIPP panel to calculate the probabilities for the 1990 calendar year, we find that 9.1 percent of native and 12.8 percent of immigrant households received cash assistance at some point during 1990 . These probabilities are higher than those reported by the Census data. Census respondents, however, may not report relatively short spells of recipiency, so that the Census may underestimate the true extent of participation.

7 The inclusion of school lunches and breakfasts increases the gap even further, to nearly 10 percentage points. These school-related benefits, however, have different take-up decisions and do not have the same types of negative connotations as other welfare programs.

${ }^{8}$ To determine the sensitivity of our results, we calculated participation rates at the person level. The SIPP reports if a person was covered by AFDC, SSI, General Assistance, other cash benefits, Medicaid, WIC, or 
some problems. Immigrant households may be larger than native households and the probability that an immigrant household is "welfare-prone" could be large even if the probability that a particular person uses welfare does not differ between immigrants and natives. ${ }^{9}$ Immigrant households, in fact, are slightly larger: the typical immigrant household has 3.2 persons as compared to 2.6 persons for a native household. We will show below, however, that most of the welfare gap between immigrants and natives remains unexplained when we control for variables describing the household's size and composition. ${ }^{10}$

We also restricted our analysis to persons who were householders at the beginning of the sample period and who remained in the SIPP files throughout the entire 32-month period. This sample restriction makes the data drawn from all the panels comparable to that drawn from the 1984 panel (which contains immigration information only if the person remained in the survey until the 32nd month). There is considerable attrition in the sample of persons who were initially householders; the attrition rate is 23.1 percent for immigrants and 22.3 percent for natives. The estimated welfare gap will be biased if the attrition process differs between immigrants and natives (perhaps due to nonrandom return migration among immigrants). Our results, however, are not

Food Stamps, and provides information on country of birth only for persons aged 15 or over. In this sample of adults (and using the 1990/1991 panels), the probability that a person was covered by at least one of these programs was 11.9 percent for immigrants and 7.7 percent for natives. Therefore, the immigrant-native welfare gap is sizable even at the person level. These probabilities, however, may underestimate the "Irue" welfare gap if immigrant households contain more children than native households, and if immigrant children have a greater probability of being covered by such programs as AFDC or WIC.

${ }^{9}$ This argument makes an assumption about the correlation in the probability that various persons are covered by particular programs. If this probability is constant in the population, the probability that someone in the household receives welfare is larger for groups that have larger households. However, if the probability is perfectly correlated within a household but independent across households, the probability that a household receives assistance need not depend on household size.

${ }^{10}$ An additional problem with using household data is that some households contain unrelated persons. In 1990, 5.2 percent of both immigrant and native households contained at least one such unrelated person. The welfare gap between immigrants and natives barely changes when we delete these households from the study. 
altered when the information provided by the households who eventually left the sample is included in the calculations. ${ }^{11}$ The average monthly probability that a household receives either cash benefits, Medicaid, vouchers, or housing subsidies (calculated over all household-months in the sample of persons who were householders at the beginning of the sample period) is 20.7 percent for immigrants and 14.7 percent for natives, a gap of 6.0 percent points. The respective gap reported in Table II is 6.6 percentage points.

We also omitted split-off households from the study. If we include split-off households, the number of both immigrant and native households increases by 12.3 percent. Split-off households have a greater propensity to receive benefits, but the inclusion of these households does not change the welfare gap substantially. ${ }^{12}$ The average monthly probability calculated over all households (regardless of whether they leave the sample and of whether they are split-offs) was 20.9 percent for immigrants and 15.1 percent for natives, a gap of 5.8 percentage points. Therefore, the biases created by focusing on households that were in the SIPP data throughout the entire sample period are not very serious.

In addition to indicating if a household receives a particular type of benefit, the SIPP reports the dollar value of the benefits received in many of the programs. Each household reported the value of cash benefits and vouchers received. There is no information, however, on the value of the benefits received from Medicaid, housing subsidies, or school breakfasts and lunches. We used administrative data specific to the household's state of residence to impute a

11 In the 1990/1991 SIPP, the welfare participation rate of households who disappeared from the panel was 21.0 percent for immigrants and 18.8 percent for natives.

12 In the 1990/1991 SIPP, the welfare participation rate of split-off households was 23.9 percent for immigrants and 21.9 percent for natives. 
dollar amount for benefits received by a household under each of these programs. For example, to calculate the value of the benefits received from Medicaid, we multiplied the number of persons in the household covered by Medicaid times the per-recipient cost in the state. ${ }^{13}$

We use these benefit amounts to calculate the fraction of benefits that are received by immigrant households. Table III shows that immigrant households account for a disproportionately large fraction of the costs of these programs. In the early $1990 \mathrm{~s}, 8.0$ percent of the households were foreign-born, and these households contained 8.8 percent of all persons in the country. These immigrant households accounted for 16.6 percent of the costs of the AFDC program, 18.4 percent of the costs of SSI, 11.5 percent of the costs of food stamps, 14.1 percent of the costs of Medicaid, and 19.0 percent of the costs of subsidized school breakfasts and lunches. In sum, the 8.8 percent of persons residing in immigrant households accounted for 13.8 percent of the costs of the programs, almost 60 percent more than their representation in the population.

We continue our descriptive analysis by showing the dispersion that exists in welfare participation among national origin groups in the immigrant population. Table IV shows that some of the groups have very high participation rates. About 36 percent of the households originating in Mexico, 42 percent of those in the former Soviet Union, and over 50 percent of those originating in the Dominican Republic received some type of benefit (defined as cash benefits, Medicaid, vouchers, or housing subsidies). Moreover, the welfare participation rates experienced by some of the immigrant groups exceeds that of native groups that have high

13 The state-specific per-recipient cost for Medicaid was obtained from U.S. House of Representatives [1986, 1992]. The state-specific per-recipient cost for school lunches was obtained from U.S. Bureau of the Census [1986, 1992]. We could not find state-specific costs for housing subsidies and for the school breakfast program, so that we use the national per-recipient cost. These data are reported in U.S. House of Representatives [1986, 1992]. 
participation rates. For example, 33 percent of Hispanic natives and 39 percent of black natives participated in some welfare program.

Earlier studies of immigrant participation in cash benefit programs have stressed the distinction between refugees and nonrefugees to explain the high usage rates among immigrants. Because the SIPP files do not report if a particular household entered the United States with a refugee visa, we assume that immigrants who originated in the main refugee-sending countries are refugees. ${ }^{14}$ The data reported in Table IV suggest a large difference in the extent to which refugees and non-refugees receive both cash benefits and other programs: 20 percent of nonrefugee and 28 percent of refugee households participate in some welfare program. Nonrefugee households, however, have substantially larger welfare participation rates than native households (where the participation rate is 14.1 percent). In other words, the welfare gap between immigrants and natives cannot be explained away by the presence of a large number of refugee households.

In effect, our discussion has described the differences in the average fraction of time that immigrant and native households receive some type of assistance. We conclude our description of the data by illustrating how the distribution of time spent on welfare differs between the two groups. Consider, for example, the definition of welfare which includes cash benefits, Medicaid, and vouchers. ${ }^{15}$ The $1990 / 1991$ data reveal that only 68.7 percent of immigrant households did not participate in these programs at any point in the 32-month period, as compared to 77.3

\footnotetext{
${ }^{14}$ The refugee-sending countries identified in the SIPP are Cuba, Czechoslovakia, Hungary, Poland, the former USSR, and Vietnam.

${ }^{15}$ Our discussion of spell incidence and duration uses the definition of welfare which does not include housing subsidies. The inclusion of housing subsidies would mar the interpretation of a spell because persons who live in public housing are not evicted in the period they become ineligible.
} 
percent of native households. Moreover, 10.3 percent of the immigrant households received welfare benefits throughout the entire 32 -month period, as compared to only 7.3 percent of native households. Put differently, immigrants are more likely to have an exposure to the welfare system and are also more likely to become "permanent" recipients.

Table V shows how the frequency and duration of welfare spells differs between immigrants and natives. In the early 1990s, immigrant households had a 24.1 percent probability of experiencing one spell of welfare, and a 7.2 percent probability of experiencing at least two spells. In contrast, only 17.8 percent of natives experienced one spell and 5.9 percent experienced at least two spells.

The interpretation of spell duration in the SIPP is complicated by the fact that a very large fraction of the first spells are left-censored (i.e., the spells are ongoing at the time the SIPP panel begins). About 54 percent of the first welfare spells observed among immigrants and 53 percent of those observed among natives are left-censored. We do not have any information on when this spell began. However, the data indicate that immigrants have longer welfare spells regardless of whether the spell is left-censored. If the spell is not left-censored, the observed mean duration of the typical spell experienced by an immigrant in 1990/1991 is 9.5 months, while that of a native is only 7.8 months. Similarly, the observed mean duration of a left-censored welfare spell is 23.8 months for immigrants and 23.0 months for natives. Table $\mathrm{V}$ helps us understand why immigrant households spend a much larger fraction of their time receiving welfare benefits: immigrants have more welfare spells and these spells are longer.

\section{Determinants of Differences Between Immigrants and Natives}


The descriptive analysis in the previous section addresses the first-order policy question of whether immigrants use welfare programs more often than natives. Nevertheless, it is of interest to determine if differences in observable demographic characteristics between the two groups explain the welfare gap and the growth in immigrant welfare recipiency observed between the mid-1980s and the early 1990s. We pooled the four SIPP panels to estimate the regression

$$
P_{i}=X_{i} \phi+\delta_{1} I_{i}+\delta_{2}\left(I_{i} \times T_{i}\right)+\varepsilon_{i}
$$

where $P_{i}$ gives the fraction of time that household $i$ received a particular type of assistance; $X_{i}$ is a vector of variables describing demographic characteristics of the household (measured as of the time the panel begins); $I_{i}$ is a dummy variable indicating if the householder is foreign-born; and $T_{i}$ is a dummy variable indicating if the observation was drawn from the 1990/1991 SIPP panels (as opposed to the $1984 / 1985$ panels). ${ }^{16}$

Table VI reports the estimates of $\delta_{1}$ and $\delta_{2}$ for various specifications of equation (1). The first column includes only "period effects" in the vector $X$ (indicating the SIPP panel from which the observation was drawn), and the second column adds variables describing the household's composition, including the number of persons (by gender) aged 5 or less, aged 18 or less, aged 18-34, aged 35-54, aged 55-64, and aged 65 or more. The regressions show that differences in

16 The dependent variable in equation (1) ranges from 0 to 1 . We present the OLS coefficients (and White standard errors) to ease the interpretation of the evidence. We estimated the models using a grouped probit specification and obtained very similar results. To further test the sensitivity of our results, we also estimated probit models using a householder/month as the unit of observation, thus allowing for time-varying covariates. Because of the very large sample size (over 1 million observations) and the large number of regressors (over 100 regressors in some of the specifications), we used random samples of the native population. The results were similar to those presented in Table 6. 
household composition account for only 1 to 2 percentage points of the welfare gap between immigrants and natives. ${ }^{17}$ Moreover, differences in household composition do not help explain why the gap rose rapidly in the late 1980 s.

The third column of the table adds variables describing the socioeconomic background of the householder, including the householder's age (and its squared), education, and gender. These variables (particularly education) help explain another 2 to 3 percentage points of the welfare gap. In other words, immigrants tend to receive more welfare not because they are immigrants, but because their socioeconomic characteristics are highly correlated with welfare use. This result has important implications for immigration policy: A small number of observable socioeconomic characteristics can be used to screen the pool of potential immigrants and to assess the probability that a visa applicant will become a welfare recipient upon entry in the United States. ${ }^{18}$

The fourth column controls for state of residence effects by including state fixed effects and the state's unemployment rate at the time the SIPP panel began, and the last column adds the householder's race and includes fixed effects indicating the householder's national origin (if the householder is foreign born). ${ }^{19}$ The regressions suggest that part of the growth in welfare recipiency during the late 1980 s can be attributed to these variables (particularly the national

17 It has been argued that much of the welfare gap may be due to the presence of elderly immigrants in the household [Fix and Passel 1994]. Although our regressions suggest that this is not the case, we also calculated the participation rates in households where no one is aged 65 or over. In 1990/1991, 17.0 percent of (non-elderly) immigrant households and 12.9 percent of native households received cash benefits, Medicaid, vouchers, or housing assistance. The presence of elderly persons in the household accounts for 1.6 percentage points of the total 6.6 percentage point gap.

${ }^{18}$ Baker and Benjamin [1995] study the relationship between immigration and welfare participation in Canada and find that immigrants in Canada (which generally uses a point system based on observable socioeconomic characteristics to award entry visas) are less likely to receive welfare benefits than natives.

19 The coefficient of the foreign-born dumny variable reported in the table is evaluated at the mean value of the national origin fixed effects. 
origin fixed effects). Note, however, that about two-thirds of the growth in immigrant welfare recipiency (relative to natives) remains unexplained.

The regression coefficients reported in Table VI suggest that controlling for observable socioeconomic characteristics reduces the welfare gap between immigrants and natives by as much as 5 percentage points. Even though differences in socioeconomic characteristics explain why the "typical" immigrant is more likely to receive welfare benefits than the typical native, there remains substantial heterogeneity within the immigrant population even after we control for these background variables. Previous research, for example, has stressed the importance of cohort and aging effects in the immigrant population. In particular, synthetic cohorts created from decennial Census data suggest that more recent immigrant cohorts are more likely to participate in welfare programs than earlier cohorts and that immigrants in a particular cohort of arrival are more likely to receive benefits the longer they have lived in the United States (Borjas and Trejo, 1991; Borjas, 1995). To determine if these trends are also observed in the SIPP files, we estimated the regression model

$$
P_{i}=X_{i} \phi+\delta I_{i}+\alpha y_{i}+\theta A_{m}+\sum_{j} \beta_{j} C_{i j}+\varepsilon_{i}
$$

where $y_{i}$ gives the number of years that an immigrant household has resided in the United States and is introduced as a second-order polynomial $\left(y_{i}\right.$ takes on the value of zero for native households); $A_{m}$ gives the immigrant householder's age at migration (and is set to zero for native households); and $C$ is a vector of dummy variables indicating the calendar year in which the immigrant household arrived in the United States (the variables in the vector indicate if the household migrated in 1980-1984, 1975-1979; 1970-1974; 1965-1969; 1960-1964; and prior to 
1960; the omitted dummy indicates if the household migrated after 1985). Initially, the vector $X$ includes only a second-order polynomial in the householder's age as well as a set of dummy variables indicating from which SIPP panel the observation was drawn. Because the age of the householder is included in $X$, the coefficient $\alpha$ measures the aging or assimilation effect (i.e., the rate at which the immigrant and native welfare participation probabilities converge or diverge over time). The coefficient vector $\beta$ summarizes the cohort effects (i.e., how the probability of welfare participation at the time of entry differs across cohorts). ${ }^{20}$

The first column of Table VII reports the basic specification of equation (2) using the definition of welfare which includes cash benefits, Medicaid, or vouchers. Three findings, which echo results obtained from Census data, are of particular interest. First, more recent immigrant waves have a higher probability of receiving benefits than earlier waves. In particular, the entry participation rate of the most recent arrivals (i.e., those who migrated after 1985) exceeds the entry participation rate of those who entered the United States in the early 1970 s by about 15 percentage points. Second, the probability of receiving welfare benefits increases the longer the household has resided in the United States. If we "track" a particular wave across SIPP panels, the probability of welfare participation increases by about 4 percentage points over a 5 -year period relative to the change experienced by native households. Finally, age-at-migration has a positive impact on welfare participation. Immigrant households that arrive in the United States at a later point in the life cycle are much more likely to receive welfare benefits.

${ }^{20}$ To identify aging, period, cohort, and age-at-migration effects, we assume that the coefficients of the period effects are the same for immigrants and natives, and that the coefficient of the age variable is the same for immigrants and natives. Borjas [1995] provides a more detailed discussion of these identification restrictions. 
Because the regression reported in column (1) has one observation per household, the estimated aging effects arise from tracking synthetic cohorts across the various SIPP panels. The SIPP data, however, permit us to track a single household over a 32 -month sample period. We can stack the monthly observations within each household (so that a householder-month becomes an observation), and estimate a version of equation (2) which includes a vector of household fixed effects. The estimated regression (and White standard errors) is given by

$$
P_{i t}=\begin{gathered}
0.0096 y_{i t}-0.0002 y_{i t}^{2}, \\
(0.0051)(0.0001)
\end{gathered}
$$

where $P_{i t}$ is a dummy variable indicating if household $i$ received benefits in month $t .{ }^{21}$ Equation (3) shows that there exists an aging effect into welfare within a single immigrant household. In fact, an immigrant household is about 4 percentage points more likely to enter the welfare system over a 5-year period than a native household.

The second column of Table VII shows what happens to the aging and cohort effects if we control for an extensive vector of demographic characteristics. The vector $X$ is expanded to include variables describing the household's size and composition, the householder's socioeconomic background, the state of residence, and the householder's race and national origin. Cohort effects remain important even after we control for this detailed vector of demographic variables, although a part of the cohort effects is explained by these explanatory variables. For example, the unadjusted entry gap between the 1960-1964 cohort and the 1980-1984 cohort is 17 percentage points. Controlling for the demographic characteristics (particularly race and national origin) reduces the entry gap between these two cohorts to about 9 percentage points. Changes

21 The regression has 1,322,656 observations (or 41,333 households times 32 months), and is estimated using the linear probability model. The standard errors account for the fact that each household contributes 32 observations. The only other variables in the regression are the householder's age and age squared. 
in observable characteristics of immigrants, therefore, account for about half of the cohort effects observed between the early 1960 s and the early 1980 s. $^{22}$

It is of interest to determine which welfare programs generate the strong cohort and aging effects estimated in column (1). We calculated a variable for each household giving the fraction of time that the household received a particular type of benefit over the sample period. We used these probabilities to estimate the regression model in equation (2) for the various programs. The remaining columns of Table VII report selected coefficients. The data suggest that recent cohorts are more likely to receive various types of welfare benefits than earlier arrivals, but that this trend is strongest for Medicaid. The probability of Medicaid coverage for immigrants who arrived after 1985 exceeds the respective probability for immigrants who arrived between 1970 and 1974 by 15.8 percentage points. The coefficients reported in Table VII also show that there is a strong aging effect into Medicaid. Relative to natives, the probability that an immigrant household receives Medicaid benefits increases by 4.9 percentage points over a 5 -year period. ${ }^{23}$

\section{Networks, National Origin, and Welfare Participation}

An interesting feature of the data presented in Table IV is that some national origin groups tend to receive particular types of benefits, and tend to "avoid" other welfare programs. For example, even though Mexican immigrants are 50 percent more likely to receive energy assistance

\footnotetext{
22 The regressions also indicate that much of the aging effect disappears once we control for socioeconomic characteristics. In fact, if we reestimate the fixed-effect regression in equation (3) in the sample of households that do not have any elderly persons (aged 65 or over), the coefficients (and White standard errors) of years-since-migration and its squared are $0.0055(0.0055)$ and $-0.0001(0.0001)$. An important part of the aging effect, therefore, seems to be generated by elderly immigrants entering various programs.

${ }^{23}$ We also analyzed the determinants of the number of spells and of the duration of the first spell, and found that more recent immigrant waves experience more and longer spells, and that the number and duration of spells increases the longer the immigrant household has been in the United States.
} 
than Cuban immigrants, Cuban immigrants are more likely to receive housing subsidies than Mexican immigrants. The link between national origin and participation in specific welfare programs raises an interesting question: Are there networks operating within national origin groups which transmit information about particular programs to newly arrived immigrants?

Anecdotal evidence suggests that ethnic communities transmit some information regarding welfare programs to potential immigrants or to newly arrived immigrants. Barnett (1993) and Matloff (1994) report that Russian- and Chinese-language newspapers provide detailed information about the application process and eligibility requirements for particular programs. For example, Matloff [1994, p. 24] found that "a popular Chinese language book on life in America sold in Taiwan, Hong Kong and Chinese bookstores in the United States includes a 36page guide to SSI and other welfare benefits" and that the "World Journal, the largest Chineselanguage newspaper in the United States, runs a 'Dear Abby'-style column on immigration matters, with welfare dominating the discussion."

We investigate the hypothesis that information about welfare programs is transmitted within networks organized along national origin lines by determining if the participation of newly arrived immigrants depends on the participation history of the existing stock of immigrants in the national origin group. In particular, we use the 1984/1985 SIPP panels to calculate the fraction of time that the typical household in national origin group $j$ participated in a particular welfare program $\left(p_{j}\right)$. We then use the $1990 / 1991$ SIPP panels to calculate the fraction of time a particular household that has just entered the United States (in 1985-1990) uses the same program, say $q_{i j s}$ for household $i$ in group $j$ residing in state $s$. Let $\bar{p}_{j}$ be the probability that the immigrant stock enumerated in the 1984 and 1985 SIPP files received either cash benefits, 
Medicaid, or vouchers. Finally, let $\bar{q}_{s}$ be the 1990/1991 participation rate of natives in state $s$ in the program under study. We estimate the regression model

$$
q_{i j s}=X_{i j s} \beta+\alpha_{1} p_{j}+\alpha_{2} \bar{p}_{j}+\alpha_{3} \bar{q}_{s}+\varepsilon_{i j s},
$$

where $X_{i j s}$ is a vector of standardizing characteristics, including household size and composition, the householder's socioeconomic background, and a variable indicating if the household resides in a metropolitan area. The least-squares regression uses a random effects estimator to allow for the possibility that the stochastic error in (4) includes a group-specific component.

The regression in (4) is estimated separately for a number of the programs that make up the welfare state. The coefficient $\alpha_{1}$ isolates the impact of the group's participation in particular programs, holding constant the group's overall propensity to receive benefits from the welfare state as well as the "generosity" of the state where the immigrant household resides. This correlation, of course, is related to the models of social capital and ethnic capital that stress the existence of human capital externalities in determining socioeconomic outcomes [Loury 1977; Coleman 1988; Borjas 1992].

The relevant coefficients are reported in rows (1) of Table VIII for a number of programs. The coefficient $\alpha_{1}$ is positive and significant for practically every single welfare program (the notable exception being school breakfasts and lunches), the coefficient $\alpha_{2}$ is smaller and often negative; and the coefficient $\alpha_{3}$ is positive (with a coefficient larger than its standard error) for only two programs. In other words, holding constant the household's demographic background, the overall propensity of the national origin group to receive some type of welfare benefit, and the 
generosity of the state of residence, the more "exposed" the group has been to a particular program in the past the larger the probability that new immigrants will also participate in that program. The size of this correlation is numerically important. A 10 percentage point increase in the fraction of the immigrant stock who receive a particular program implies about a 10 point increase in the probability that a newly arrived immigrant also receives benefits from that program. In rows (2) of the table, we use state fixed effects rather than the welfare participation rate of natives in the state to control for the state's provision of particular programs. Our results do not change when we use this more general specification.

The strong correlation between the propensity of earlier immigrant waves to receive particular types of assistance and the propensity of newly arrived immigrants to receive the same types of assistance is consistent with the existence of networks within the immigrant community, organized along national origin lines. These networks transmit information about the availability of particular types of benefits to newly arrived immigrants. ${ }^{24}$ This correlation, however, can also arise because the regression specified in equation (4) does not control for all the variables that determine whether households in a particular national origin group qualify for, apply for, and receive particular types of assistance. To the extent that our regression does not control for all the relevant variables, the probability that persons in a particular national origin group have received this type of assistance in the past would then be correlated with these omitted variables. As a result, the results reported in Table VIII may be simply an artifact of omitted variable bias.

\footnotetext{
${ }^{24}$ It would be of interest to determine if the information networks are related to the ethnic composition of the neighborhood, but the SIPP files do not provide detailed geographic information. The regressions, however, include a variable indicating if the household resided in one of the metropolitan areas identified in the SIPP.
} 
It is very difficult to assess the relative importance of omitted variables in generating our results. We do not believe, however, that omitted variable bias can explain the entire correlation. After all, the regression specification already includes a measure of the ethnic group's propensity to participate in some welfare program $\left(\bar{p}_{j}\right)$, and controls for many of the key observables that determine participation. To the extent that the national origin group's propensity to participate in some program captures many of the unobserved factors that motivate households in some groups to enroll in welfare programs, the regression isolates the relative importance of networks in providing information about specific programs. Moreover, the regressions also control for the state's provision of particular programs. Interestingly, the variable giving the fraction of natives in the state who benefit from a specific program has a sizable impact only for AFDC and Medicaid, the two programs in which states pay a large fraction of the costs. ${ }^{25}$ If the grouped variables simply proxied for omitted factors, the state variable would likely be significant even for programs where the state plays little role in determining eligibility and benefit levels. The empirical analysis, therefore, suggests that networks which transmit information about welfare benefits might indeed be operating within immigrant communities.

\section{Summary}

This paper used data drawn from the Survey of Income and Program Participation to analyze the trends in immigrant participation for a variety of means-tested entitlement programs. The empirical evidence provides a number of potentially important findings:

25 The federal government pays about 56 percent of the total costs of AFDC and Medicaid, 79 percent of the costs of SSI, and over 90 percent of the costs of the other programs listed in Table VIII; see U.S. Bureau of the Census [1992, p. 357]. 
1. Immigrant households are much more likely to receive some type of welfare benefit than native households. The data indicate that 20.7 percent of immigrant households received either cash benefits, Medicaid, vouchers, or housing subsidies as compared to 14.1 percent of native households. This welfare gap between immigrants and natives is much larger than the gap suggested by earlier studies (which focus on cash benefits). Moreover, the welfare gap increased rapidly between the mid-1980s and the early 1990s. Although much of the welfare gap can be accounted for by differences in socioeconomic characteristics between the two populations, these variables explain only about a third of the rapid growth observed in the past decade.

2. Immigrant households have more spells of welfare and these spells are longer. As a result, the typical immigrant household has a much higher propensity of being "permanently" on welfare. The probability that an immigrant household receives some type of benefit for at least 75 percent of the sample period covered by the SIPP is 13.4 percent, as compared to 9.1 percent for native households.

3. There are sizable cohort effects (with more recent cohorts being more likely to receive welfare benefits) and assimilation effects (with a particular immigrant household being more likely to receive benefits the longer the household has resided in the United States). These effects are strongest for participation in the Medicaid program.

4. The types of welfare benefits received bỹ earlier immigrant waves influence the types of welfare benefits received by newly arrived immigrants. This correlation suggests that there might be information networks operating within ethnic communities which transmit information about the availability of particular types of benefits to newly arrived immigrants. 
Because of the potential implications of our results, it is important to stress the many limitations of the study. For example, the short sample period in the SIPP panels (each household is followed for only 32 months) precludes a full analysis of the dynamics of welfare dependency in immigrant and native households. Similarly, little is known about the long-run impact of welfare dependency in the immigrant generation in terms of the economic and social outcomes of secondgeneration Americans. Finally, we did not analyze the net economic impact of immigrant welfare recipiency. Even though many accounting exercises purport to calculate the fiscal costs and fiscal benefits of immigration (i.e., compare welfare expenditures with taxes paid by immigrant households), these calculations miss the point. The costs and benefits of welfare, both among immigrants and natives, have little to do with the "bottom line" of a ledger sheet. To assess the net impact of the trends in immigrant welfare recipiency, we have to account for the long-run benefits of such programs as subsidized lunches to school-aged children or food vouchers to mothers in terms of improving the nutrition and health of immigrant children. At the same time, however, we have to determine if these programs reduce the work incentives of current immigrants and change the nature of the immigrant flow by influencing the migration decisions of potential migrants in the source countries. 


\section{REFERENCES}

Baker, Michael, and Benjamin, Dwayne, "The Receipt of Transfer Payments by Immigrants in Canada," Journal of Human Resources, forthcoming 1995.

Barnett, Don, “Their Teeming Shores,” National Review, (November 1, 1993), 51-55.

Blau, Francine D., "The Use of Transfer Payments by Immigrants," Industrial and Labor Relations Review, XXXVII (January 1984), 222-239.

Borjas, George J., "Ethnic Capital and Intergenerational Mobility," Quarterly Journal of Economics, CVII (February 1992), 123-150.

, "Assimilation and Changes in Cohort Quality Revisited: What Happened to Immigrant Earnings in the 1980s?" Journal of Labor Economics, XIII (April 1995), 201245. (1995), 251-280.

"Immigration and Welfare, 1970-1990," Research in Labor Economics, XIV

Borjas, George J., and Stephen J. Trejo, "Immigrant Participation in the Welfare System," Industrial and Labor Relations Review, XLIV (January 1991), 195-211.

Coleman, James S., "Social Capital in the Creation of Human Capital," American Journal of Sociology, XCIV (Supplement 1988), S95-120.

Fix, Michael and Jeffrey S. Passel, Immigration and Immigrants: Setting the Record Straight (Washington, DC: Urban Institute, 1994).

Jensen, Leif, "Patterns of Immigration and Public Assistance Utilization, 1970-1980," International Migration Review, XXII (Spring 1988), 51-83.

Loury, Glenn C., "A Dynamic Theory of Racial Income Differences," in P. A. Wallace and A. L. Lamond, eds., Women, Minorities, and Employment Discrimination (Lexington, MA: Lexington Books, 1977), 153-186.

Matloff, Norman, "From 'Jiu Ji Jin' to 'Fu Li Jin': Some Chinese Immigrants Mistakenly See Welfare as a 'Fringe Benefit'," The New Democrat (November 1994), 23-25.

Singh, Rajendra P., Lynn Weidman, and Gary M. Shapiro, "Quality of SIPP Estimates," in H. Beaton, D. Ganni, and D. Frankel, eds., Individuals and Families in Transition: Understanding Change Through Longitudinal Data (Washington, DC: U.S. Bureau of the Census, 1989), 301-332. 
U.S. Bureau of the Census, Statistical Abstract of the United States, (Washington, DC: Government Printing Office, various issues).

U.S. General Accounting Office, Supplemental Security Income: Recent Growth in the Rolls Raises Fundamental Program Concerns, (Washington, DC: U.S. General Accounting Office, January 27, 1995).

U.S. House of Representatives, Background Material and Data on Programs within the Jurisdiction of the Committee on Ways and Means (Green Book), (Washington, DC: U.S. Government Printing Office, various issues). 


\begin{tabular}{lc}
\hline \hline & Annual Costs \\
Program description & (Billions of \\
Dollars)
\end{tabular}

Cash programs:

Aid to Families with Dependent Children (AFDC): Provides means-tested cash benefits to low income single parent households.

Supplemental Security Income (SSI): Provides means-tested cash benefits to needy aged, blind, and disabled persons.

General Assistance: Means-tested cash benefits for needy persons who do not qualify for one of the federally assisted programs.

Noncash programs:

Medicaid: Provides medical assistance for low income persons who are aged, blind, disabled, members of families with dependent children, certain other pregnant women and children, and other qualified medically needy persons.

Food Stamps: Distributes vouchers designed to increase the food purchasing power of eligible low-income households.

Special Supplemental Food Program for Women, Infants, and Children (WIC): Provides food, food vouchers, and nutritional screening to low-income pregnant and postpartum women and their infants, as well as children up to age 5 .

Low Income Energy Assistance: Helps low-income households meet their energy-related expenses.

Housing Assistance: Participating households can live in low-rent housing built by the government (i.e., public housing) or live in private housing and receive government subsidies for their rent.

School Lunch and Breakfast Programs: Distributes free or reduced price breakfasts and lunches to low-income children enrolled in school.

Sources: U.S. House of Representatives [1993] and U.S. Bureau of the Census [1993]. The costs for each of the programs include the expenditures incurred at all levels of government (federal, state, and local). The costs of general assistance are for the 1990 fiscal year. 
TABLE II

AVERAGE MONTHLY PROBABILITY OF RECEIVING BENEFITS

\begin{tabular}{|c|c|c|c|c|}
\hline \multirow[b]{2}{*}{ Type of benefit: } & \multicolumn{2}{|c|}{$\underline{1984 / 1985}$} & \multicolumn{2}{|c|}{$\underline{1990 / 1991}$} \\
\hline & $\begin{array}{c}\text { Native } \\
\text { households }\end{array}$ & $\begin{array}{l}\text { Immigrant } \\
\text { households }\end{array}$ & $\begin{array}{c}\text { Native } \\
\text { households }\end{array}$ & $\begin{array}{l}\text { Immigrant } \\
\text { households }\end{array}$ \\
\hline \multicolumn{5}{|l|}{ Cash programs: } \\
\hline $\begin{array}{l}\text { Aid to Families with Dependent Children } \\
\text { (AFDC) }\end{array}$ & 2.8 & 2.6 & 2.9 & 4.4 \\
\hline Supplemental Security Income (SSI) & 3.7 & 5.1 & 3.7 & 6.5 \\
\hline General Assistance & 0.9 & 1.0 & 0.6 & 0.8 \\
\hline \multicolumn{5}{|l|}{ Noncash programs: } \\
\hline Medicaid & 8.4 & 11.0 & 9.4 & 15.4 \\
\hline Food stamps & 6.6 & 7.6 & 6.5 & 9.2 \\
\hline $\begin{array}{l}\text { Supplemental Food Program for Women, } \\
\text { Infant and Child (WIC) }\end{array}$ & 1.4 & 1.8 & 2.0 & 3.0 \\
\hline Energy Assistance & 2.9 & 2.8 & 2.3 & 2.1 \\
\hline $\begin{array}{l}\text { Housing Assistance (Public Housing or Low } \\
\text { Rent Subsidies) }\end{array}$ & 4.0 & 5.7 & 4.4 & 5.6 \\
\hline $\begin{array}{l}\text { School breakfasts and lunches (free or } \\
\text { reduced price) }\end{array}$ & 5.7 & 10.1 & 6.2 & 12.5 \\
\hline \multicolumn{5}{|l|}{ Summary statistics: } \\
\hline Receive any cash benefits & 8.1 & 8.7 & 7.3 & 10.8 \\
\hline Receive cash benefits or Medicaid & 9.6 & 11.5 & 10.0 & 15.7 \\
\hline $\begin{array}{l}\text { Receive cash benefits, Medicaid, or } \\
\text { vouchers (which include Food Stamps, } \\
\text { WIC, and energy assistance) }\end{array}$ & 12.7 & 15.2 & 12.3 & 18.2 \\
\hline $\begin{array}{l}\text { Receive cash benefits, Medicaid, vouchers, } \\
\text { or housing assistance }\end{array}$ & 14.6 & 17.7 & 14.1 & 20.7 \\
\hline $\begin{array}{l}\text { Receive any type of assistance (cash } \\
\text { benefits, Medicaid, vouchers, housing } \\
\text { assistance, or school breakfasts and } \\
\text { lunches) }\end{array}$ & 16.5 & 22.6 & 16.3 & 26.1 \\
\hline Number of households & 12,630 & 914 & 25,340 & 2,449 \\
\hline Number of observations & 404,160 & 29,248 & 810,880 & 78,368 \\
\hline
\end{tabular}


TABLE III

PERCENT OF DOLLAR BENEFITS DISTRIBUTED TO IMMIGRANT HOUSEHOLDS

\begin{tabular}{lrr}
\hline \hline Type of benefit:: & $1984 / 1985$ & $1990 / 1991$ \\
\hline Cash programs: & 10.0 & 16.0 \\
$\quad$ Aid to Families with Dependent Children (AFDC) & 9.5 & 16.6 \\
$\quad$ Supplemental Security Income (SSI) & 13.1 & 18.4 \\
Voucher programs (Food Stamps, WIC, and energy assistance): & 7.6 & 11.2 \\
$\quad$ Food Stamps & 8.0 & 11.5 \\
& & 14.5 \\
Cash programs and voucher programs & 9.3 & 14.1 \\
Other programs: & & 9.9 \\
$\quad$ Medicaid & 10.1 & 19.0 \\
$\quad$ Housing assistance (public housing or low-rent subsidies) & 9.4 & 13.3 \\
$\quad$ School breakfasts and lunches & & 13.8 \\
& & \\
All programs & 9.8 & 8.0 \\
Percent of households that are foreign-born & & 8.8 \\
Percent of persons living in foreign-born households & 7.3 & \\
\hline \hline
\end{tabular}

Note: The SIPP provides information on the dollar value of the benefits received by the household in cash and voucher programs. The dollar value of the benefits received by "other programs" is imputed using state-specific administrative data; see text for details. 
TABLE IV

AVERAGE MONTHLY PROBABILITY OF RECEIVING BENEFITS IN 1990/1991, SELECTED NATIONAL ORIGIN GROUPS

\begin{tabular}{|c|c|c|c|c|c|c|c|c|c|c|c|c|}
\hline Country of Birth & AFDC & SSI & $\begin{array}{c}\text { Food } \\
\text { Stamps }\end{array}$ & $\begin{array}{c}\text { Energy } \\
\text { assistance }\end{array}$ & Medicaid & $\begin{array}{l}\text { Housing } \\
\text { subsidies }\end{array}$ & $\begin{array}{c}\text { School } \\
\text { lunches }\end{array}$ & $\begin{array}{c}\text { Any } \\
\text { cash } \\
\text { benefits }\end{array}$ & $\begin{array}{c}\text { Cash } \\
\text { Medicaid, } \\
\text { vouchers }\end{array}$ & $\begin{array}{c}\text { Cash, } \\
\text { Medicaid, } \\
\text { vouchers, } \\
\text { housing }\end{array}$ & $\begin{array}{c}\text { Any } \\
\text { benefits }\end{array}$ & $\begin{array}{l}\text { Number of } \\
\text { Households }\end{array}$ \\
\hline \multicolumn{13}{|l|}{ Europe: } \\
\hline Germany & 0.8 & 1.6 & 4.1 & 1.2 & 4.3 & 1.5 & 2.1 & 3.6 & 6.6 & 7.3 & 8.0 & 113 \\
\hline Greece & 0.0 & 2.9 & 1.4 & 0.7 & 4.6 & 2.6 & 2.6 & 2.9 & 5.2 & 7.7 & 9.8 & 33 \\
\hline Ireland & 0.0 & 3.6 & 5.1 & 3.4 & 4.9 & 0.0 & 0.0 & 5.0 & 7.8 & 7.8 & 7.8 & 26 \\
\hline Italy & 1.7 & 6.0 & 2.4 & 4.5 & 8.7 & 6.4 & 1.6 & 8.5 & 13.0 & 17.2 & 18.3 & 90 \\
\hline Poland & 2.1 & 3.3 & 4.9 & 3.0 & 7.7 & 3.7 & 2.3 & 5.4 & 9.2 & 10.7 & 10.9 & 61 \\
\hline Portugal & 0.3 & 3.9 & 0.3 & 0.2 & 5.5 & 2.7 & 6.3 & 4.2 & 7.8 & 10.5 & 16.2 & 31 \\
\hline United Kingdom & 0.2 & 2.4 & 2.5 & 0.9 & 5.2 & 2.9 & 2.4 & 2.8 & 6.8 & 9.6 & 11.3 & 95 \\
\hline USSR & 7.5 & 17.8 & 30.9 & 5.9 & 40.6 & 11.0 & 7.3 & 31.3 & 40.9 & 41.8 & 42.8 & 38 \\
\hline Other Europe & 0.6 & 1.5 & 1.9 & 1.3 & 3.0 & 1.4 & 1.0 & 2.3 & 4.2 & 5.7 & 6.2 & 89 \\
\hline \multicolumn{13}{|l|}{ Asia: } \\
\hline China & 0.3 & 8.0 & 1.3 & 0.4 & 11.8 & 6.3 & 6.3 & 8.4 & 11.9 & 14.3 & 18.9 & 114 \\
\hline India & 1.5 & 1.3 & 1.9 & 0.0 & 7.2 & 4.5 & 3.2 & 2.8 & 7.3 & 11.7 & 14.5 & 55 \\
\hline Japan & 0.0 & 7.8 & 1.0 & 0.9 & 7.8 & 0.0 & 3,1 & 7.8 & 9.3 & 9.3 & 11.7 & 33 \\
\hline Korea & 0.1 & 2.7 & 0.2 & 0.3 & 4.2 & 2.4 & 6.7 & 3.3 & 4.8 & 7.3 & 13.7 & 62 \\
\hline Middle East & 5.1 & $' 12.8$ & 12.4 & 1.6 & 22.8 & 1.2 & 9.4 & 18.5 & 23.5 & 23.5 & 25.4 & 66 \\
\hline Philippines & 1.1 & 7.3 & 3.1 & 0.0 & 10.8 & 3.6 & 2.5 & 8.4 & 11.6 & 15.2 & 16.5 & 96 \\
\hline Vietnam & 30.3 & 24.1 & 29.7 & 3.8 & 44.9 & 18.6 & 28.6 & 41.1 & 46.0 & 48.6 & 53.3 & 48 \\
\hline Other Asia & 25.8 & 17.6 & 30.2 & 5.4 & 33.2 & 8.2 & 29.5 & 32.4 & 33.8 & 34.3 & 40.5 & 53 \\
\hline \multicolumn{13}{|c|}{ North and South America: } \\
\hline Canada & 1.6 & 1.7 & 0.7 & 1.5 & 4.4 & 4.4 & 1.2 & 4.5 & 6.9 & 9.6 & 9.9 & 108 \\
\hline Central America & 4.3 & 5.8 & 11.3 & 1.9 & 22.8 & 7.4 & 25.7 & 9.6 & 27.7 & 31.5 & 43.5 & 99 \\
\hline Cuba & 0.6 & 17.5 & 15.6 & 2.3 & 22.7 & 8.9 & 5.6 & 17.8 & 24.7 & 27.5 & 29.9 & 126 \\
\hline Dominican Republic & 23.9 & 19.8 & 38.3 & 9.3 & 47.1 & 15.3 & 29.7 & 45.4 & 49.5 & 50.9 & 58.6 & 56 \\
\hline Jamaica & 1.3 & 6.8 & 3.3 & 1.6 & 11.0 & 2.5 & 9.3 & 8.1 & 12.1 & 12.8 & 19.1 & 45 \\
\hline Mexico & 6.9 & 6.2 & 17.0 & 3.0 & 26.8 & 7.9 & 35.6 & 13.7 & 33.7 & 36.0 & 51.3 & 505 \\
\hline South America & 4.0 & 4.3 & 7.7 & 1.8 & 11.4 & 5.7 & 14.1 & 8.4 & 15.0 & 18.5 & 26.1 & 128 \\
\hline Refugees & 7.4 & 13.6 & 16.9 & 3.4 & 24.1 & 9.5 & 8.8 & 19.5 & 25.6 & 27.9 & 29.9 & 312 \\
\hline Non-Refugees & 3.8 & 5.5 & 8.0 & 2.0 & 14.1 & 4.9 & 12.6 & 9.6 & 17.1 & 19.7 & 25.5 & 2,137 \\
\hline All natives & 2.9 & 3.7 & 6.5 & 2.3 & 9.4 & 4.4 & 6.2 & 7.3 & 12.3 & 14.1 & 16.3 & 25,340 \\
\hline White natives & 1.5 & 2.5 & 4.0 & 1.8 & 6.5 & 3.1 & 3.9 & 4.8 & 8.9 & 10.5 & 12.2 & 21,170 \\
\hline Black natives & 12.1 & 12.2 & 23.3 & 5.4 & 28.8 & 14.6 & 22.0 & 24.5 & 35.1 & 38.8 & 44.0 & 2,600 \\
\hline Hispanic natives & 10.0 & 9.9 & 19.4 & 5.2 & 26.0 & 10.3 & 18.5 & 20.7 & 30.9 & 33.4 & 38.1 & 1,247 \\
\hline
\end{tabular}


TABLE V

NUMBER AND DURATION OF WELFARE SPELLS

\begin{tabular}{|c|c|c|c|c|}
\hline \multirow[b]{2}{*}{ Variable: } & \multicolumn{2}{|c|}{$1984 / 1985$} & \multicolumn{2}{|c|}{$1990 / 1991$} \\
\hline & Natives & Immigrants & Natives & Immigrants \\
\hline \multicolumn{5}{|l|}{ Distribution of number of spells: } \\
\hline No spells & 75.5 & 71.7 & 77.3 & 68.7 \\
\hline 1 spell & 17.3 & 20.9 & 17.8 & 24.1 \\
\hline 2 spells & 5.3 & 5.5 & 3.7 & 5.1 \\
\hline 3 or more spells & 1.9 & 1.9 & 1.2 & 2.1 \\
\hline Number of First Spells & 3,109 & 260 & 5,743 & 766 \\
\hline \multicolumn{5}{|l|}{ First spells that are not left-censored: } \\
\hline Percent of total spells & 47.1 & 45.0 & 46.6 & 45.8 \\
\hline Mean duration (months) & 6.3 & 6.7 & 7.8 & 9.5 \\
\hline Percent that are right-censored & 19.7 & 18.8 & 30.8 & 36.8 \\
\hline \multicolumn{5}{|l|}{ First spells that are left-censored: } \\
\hline Percent of total spells & 52.9 & 55.0 & 53.4 & 54.2 \\
\hline Mean duration (months) & 20.5 & 20.7 & 23.0 & 23.8 \\
\hline Percent that are also right-censored & 46.8 & 49.7 & 60.2 & 60.7 \\
\hline
\end{tabular}

Note: The household is a welfare recipient if it receives cash benefits, Medicaid, or vouchers. 
STANDARDIZED IMMIGRANT-NATIVE DIFFERENTIAL IN PROPORTION OF TIME THAT HOUSEHOLDS RECEIVE WELFARE

\begin{tabular}{|c|c|c|c|c|c|}
\hline \multirow[b]{2}{*}{ Definition of Welfare/Variable: } & \multicolumn{5}{|c|}{ Regression Specification } \\
\hline & (1) & (2) & (3) & (4) & (5) \\
\hline \multicolumn{6}{|l|}{ Receive cash benefits: } \\
\hline Foreign-born & $\begin{array}{c}.0055 \\
(.0092)\end{array}$ & $\begin{array}{l}-.0030 \\
(.0091)\end{array}$ & $\begin{array}{l}-.0192 \\
(.0088)\end{array}$ & $\begin{array}{l}-.0257 \\
(.0090)\end{array}$ & $\begin{array}{l}-.0170 \\
(.0093)\end{array}$ \\
\hline Foreign-born $\times 1990 / 1991$ panel dummy & $\begin{array}{c}.0300 \\
(.0114)\end{array}$ & $\begin{array}{c}.0315 \\
(.0112)\end{array}$ & $\begin{array}{c}.0300 \\
(.0110)\end{array}$ & $\begin{array}{c}.0274 \\
(.0110)\end{array}$ & $\begin{array}{l}.0206 \\
(.0108)\end{array}$ \\
\hline \multicolumn{6}{|l|}{ Receive cash benefits or Medicaid: } \\
\hline Foreign-born & $\begin{array}{c}.0197 \\
(.0101)\end{array}$ & $\begin{array}{c}.0083 \\
(.0098)\end{array}$ & $\begin{array}{l}-.0116 \\
(.0095)\end{array}$ & $\begin{array}{l}-.0193 \\
(.0096)\end{array}$ & $\begin{array}{l}-.0097 \\
(.0100)\end{array}$ \\
\hline Foreign-born $\times 1990 / 1991$ panel dummy & $\begin{array}{c}.0377 \\
(.0127)\end{array}$ & $\begin{array}{l}.0380 \\
(.0123)\end{array}$ & $\begin{array}{c}.0369 \\
(.0118)\end{array}$ & $\begin{array}{c}.0336 \\
(.0118)\end{array}$ & $\begin{array}{l}.0273 \\
(.0116)\end{array}$ \\
\hline \multicolumn{6}{|l|}{ Receive cash benefits, Medicaid, or vouchers: } \\
\hline Foreign-born & $\begin{array}{c}.0248 \\
(.0110)\end{array}$ & $\begin{array}{c}.0115 \\
(.0106)\end{array}$ & $\begin{array}{l}-.0134 \\
(.0101)\end{array}$ & $\begin{array}{l}-.0155 \\
(.0102)\end{array}$ & $\begin{array}{l}-.0034 \\
(.0104)\end{array}$ \\
\hline Foreign-born $\times 1990 / 1991$ panel dummy & $\begin{array}{l}.0343 \\
(.0136)\end{array}$ & $\begin{array}{l}.0341 \\
(.0130)\end{array}$ & $\begin{array}{l}.0338 \\
(.0125)\end{array}$ & $\begin{array}{l}.0298 \\
(.0125)\end{array}$ & $\begin{array}{l}.0241 \\
(.0122)\end{array}$ \\
\hline \multicolumn{6}{|l|}{$\begin{array}{l}\text { Receive cash benefits, Medicaid, vouchers, or } \\
\text { housing subsidies: }\end{array}$} \\
\hline Foreign-born & $\begin{array}{c}.0313 \\
(.0118)\end{array}$ & $\begin{array}{c}.0206 \\
(.0114)\end{array}$ & $\begin{array}{l}-.0077 \\
(.0110)\end{array}$ & $\begin{array}{l}-.0115 \\
(.0111)\end{array}$ & $\begin{array}{l}.0023 \\
(.0113)\end{array}$ \\
\hline Foreign-born $\times 1990 / 1991$ panel dummy & $\begin{array}{l}.0346 \\
(.0146)\end{array}$ & $\begin{array}{l}.0362 \\
(.0140)\end{array}$ & $\begin{array}{c}.0367 \\
(.0134)\end{array}$ & $\begin{array}{l}.0338 \\
(.0134)\end{array}$ & $\begin{array}{r}.0287 \\
(.0133)\end{array}$ \\
\hline \multicolumn{6}{|l|}{$\begin{array}{l}\text { Receive cash benefits, Medicaid, vouchers, } \\
\text { housing subsidies, or subsidized school } \\
\text { breakfasts and lunches for children: }\end{array}$} \\
\hline Foreign-born & $\begin{array}{c}.0608 \\
(.0126)\end{array}$ & $\begin{array}{c}.0432 \\
(.0117)\end{array}$ & $\begin{array}{c}.0128 \\
(.0109)\end{array}$ & $\begin{array}{c}.0124 \\
(.0110)\end{array}$ & $\begin{array}{l}.0288 \\
(.0112)\end{array}$ \\
\hline Foreign-born $\times 1990 / 1991$ panel dummy & $\begin{array}{c}.0367 \\
(.0154)\end{array}$ & $\begin{array}{c}.0366 \\
(.0142)\end{array}$ & $\begin{array}{c}.0373 \\
(.0133)\end{array}$ & $\begin{array}{c}.0330 \\
(.0132)\end{array}$ & $\begin{array}{l}.0264 \\
(.0130)\end{array}$ \\
\hline
\end{tabular}

Notes: White standard errors are reported in parentheses. The regressions have 41,333 observations. All regressions include a vector of period effects indicating if the observation was drawn from the 1984, 1985, 1990, or 1991 SIPP file. Regression (2) adds a vector of 12 variables describing the household's composition. The variables include the number of persons (by gender) under the age of 6, under the age of 18, aged 18-34, aged 35-54, aged $55-64$, and aged 65 or over. Regression (3) adds a vector of variables describing the householder's background, including the gender, education, age, and age squared of the householder. Regression (4) adds the unemployment rate in the state of residence at the time the SIPP panel began, as well as a vector of state fixed effects. Regression (5) adds a vector of fixed effects indicating the householder's race and national origin (if immigrant). 


\begin{tabular}{|c|c|c|c|c|c|c|}
\hline \multirow{2}{*}{$\frac{\text { Variable }}{\text { Foreign-born }}$} & \multicolumn{2}{|c|}{$\begin{array}{c}\text { Cash benefits, Medicaid, } \\
\text { or vouchers }\end{array}$} & \multirow{2}{*}{$\begin{array}{c}\text { AFDC } \\
0.0093 \\
(0.0225)\end{array}$} & \multirow{2}{*}{$\begin{array}{c}\text { SSI } \\
-0.0408 \\
(0.0238)\end{array}$} & \multirow{2}{*}{$\begin{array}{c}\text { Medicaid } \\
0.0438 \\
(0.0335)\end{array}$} & \multirow{2}{*}{$\begin{array}{c}\text { Food Stamps } \\
0.0042 \\
(0.0276)\end{array}$} \\
\hline & $\begin{array}{c}0.0600 \\
(0.0347)\end{array}$ & $\begin{array}{c}0.0149 \\
(0.0299)\end{array}$ & & & & \\
\hline Migrated in $1980-85$ & $\begin{array}{l}-0.0401 \\
(0.0379)\end{array}$ & $\begin{array}{l}-0.0541 \\
(0.0307)\end{array}$ & $\begin{array}{c}0.0092 \\
(0.0258)\end{array}$ & $\begin{array}{c}0.0085 \\
(0.0255)\end{array}$ & $\begin{array}{l}-0.0448 \\
(0.0369)\end{array}$ & $\begin{array}{c}0.0243 \\
(0.0333)\end{array}$ \\
\hline Migrated in 1975-79 & $\begin{array}{l}-0.1124 \\
(0.0453)\end{array}$ & $\begin{array}{l}-0.1198 \\
(0.0385)\end{array}$ & $\begin{array}{l}-0.0354 \\
(0.0300)\end{array}$ & $\begin{array}{l}-0.0349 \\
(0.0287)\end{array}$ & $\begin{array}{l}-0.1265 \\
(0.0431)\end{array}$ & $\begin{array}{l}-0.0405 \\
(0.0383)\end{array}$ \\
\hline Migrated in $1970-74$ & $\begin{array}{l}-0.1477 \\
(0.0571)\end{array}$ & $\begin{array}{l}-0.1351 \\
(0.0489)\end{array}$ & $\begin{array}{l}-0.0378 \\
(0.0375)\end{array}$ & $\begin{array}{l}-0.0255 \\
(0.0353)\end{array}$ & $\begin{array}{l}-0.1583 \\
(0.0538)\end{array}$ & $\begin{array}{l}-0.0299 \\
(0.0490)\end{array}$ \\
\hline Migrated in $1965-69$ & $\begin{array}{l}-0.1938 \\
(0.0677)\end{array}$ & $\begin{array}{l}-0.1642 \\
(0.0579)\end{array}$ & $\begin{array}{l}-0.0560 \\
(0.0430)\end{array}$ & $\begin{array}{l}-0.0481 \\
(0.0418)\end{array}$ & $\begin{array}{l}-0.1931 \\
(0.0639)\end{array}$ & $\begin{array}{l}-0.0547 \\
(0.0574)\end{array}$ \\
\hline Migrated in 1960-64 & $\begin{array}{l}-0.2133 \\
(0.0766)\end{array}$ & $\begin{array}{l}-0.1417 \\
(0.0660)\end{array}$ & $\begin{array}{l}-0.0696 \\
(0.0480)\end{array}$ & $\begin{array}{l}-0.0365 \\
(0.0486)\end{array}$ & $\begin{array}{l}-0.2163 \\
(0.0723)\end{array}$ & $\begin{array}{l}-0.0504 \\
(0.0651)\end{array}$ \\
\hline Migrated before 1960 & $\begin{array}{l}-0.2401 \\
(0.0884)\end{array}$ & $\begin{array}{l}-0.1754 \\
(0.0772)\end{array}$ & $\begin{array}{l}-0.0709 \\
(0.0517)\end{array}$ & $\begin{array}{l}-0.1108 \\
(0.0567)\end{array}$ & $\begin{array}{l}-0.2382 \\
(0.0825)\end{array}$ & $\begin{array}{l}-0.0772 \\
(0.0722)\end{array}$ \\
\hline $\begin{array}{l}\text { Years since } \\
\quad \text { migration (YSM) }\end{array}$ & $\begin{array}{c}0.0084 \\
(0.0052)\end{array}$ & $\begin{array}{c}0.0042 \\
(0.0044)\end{array}$ & $\begin{array}{c}0.0019 \\
(0.0034)\end{array}$ & $\begin{array}{c}0.0020 \\
(0.0031)\end{array}$ & $\begin{array}{c}0.0092 \\
(0.0049)\end{array}$ & $\begin{array}{c}0.0013 \\
(0.0045)\end{array}$ \\
\hline $\mathrm{YSM}^{2} \div 100$ & $\begin{array}{l}-0.0132 \\
(0.0093)\end{array}$ & $\begin{array}{l}-0.0027 \\
(0.0079)\end{array}$ & $\begin{array}{l}-0.0017 \\
(0.0054)\end{array}$ & $\begin{array}{c}0.0001 \\
(0.0058)\end{array}$ & $\begin{array}{l}-0.0148 \\
(0.0087)\end{array}$ & $\begin{array}{l}-0.0018 \\
(0.0075)\end{array}$ \\
\hline Age at migration & $\begin{array}{c}0.0019 \\
(0.0006)\end{array}$ & $\begin{array}{c}0.0020 \\
(0.0005)\end{array}$ & $\begin{array}{c}0.0006 \\
(0.0002)\end{array}$ & $\begin{array}{c}0.0027 \\
(0.0005)\end{array}$ & $\begin{array}{c}0.0023 \\
(0.0006)\end{array}$ & $\begin{array}{c}0.0016 \\
(0.0005)\end{array}$ \\
\hline $\begin{array}{l}\text { Includes other } \\
\text { demographic } \\
\text { variables }\end{array}$ & No & Yes & No & No & No & No \\
\hline $\mathbf{R}^{2}$ & 0.012 & 0.229 & 0.022 & 0.023 & 0.012 & 0.011 \\
\hline
\end{tabular}

Notes: White standard errors are reported in parentheses. The regressions have 41,333 observations and are estimated using least squares. All regressions include the höuseholder's age (and age squared) and a vector of period effects indicating if the observation was drawn from the 1984, 1985, 1990, or 1991 SIPP file. The vector of "other demographic variables" include the number of persons in the household (by gender) who are under age 5 , under age 18, 18-34, 35-54, 55-64, 65 or over, the householder's education, gender, and race, state of residence fixed effects, the state unemployment rate at the time of the survey, and fixed effects indicating the householder's national origin (if immigrant). 
THE LINK BETWEEN THE WELFARE EXPERIENCE OF NEW ARRIVALS AND THE WELFARE EXPERIENCE OF THE EXISTING IMMIGRANT STOCK

\begin{tabular}{|c|c|c|c|c|}
\hline \multirow[b]{2}{*}{ Program: } & \multicolumn{4}{|c|}{ Variable } \\
\hline & $\begin{array}{l}\text { Probability that ethnic } \\
\text { group participated in } \\
\text { program in } 1984 / 1985\end{array}$ & $\begin{array}{l}\text { Probability that group } \\
\text { received cash, Medicaid, } \\
\text { or vouchers in } 1984 / 1985\end{array}$ & $\begin{array}{l}\text { Probability that natives in } \\
\text { state participate in } \\
\text { program in } 1990 / 1991\end{array}$ & $\begin{array}{c}\text { State fixed } \\
\text { effects }\end{array}$ \\
\hline \multicolumn{5}{|l|}{ AFDC: } \\
\hline (1) & $\begin{array}{c}1.2942 \\
(0.1919)\end{array}$ & $\begin{array}{c}0.2862 \\
(0.1382)\end{array}$ & $\begin{array}{c}1.5576 \\
(1.3794)\end{array}$ & No \\
\hline (2) & $\begin{array}{c}1.1740 \\
(0.3470)\end{array}$ & $\begin{array}{c}0.3094 \\
(0.1341)\end{array}$ & --- & Yes \\
\hline \multicolumn{5}{|l|}{ SSI: } \\
\hline (1) & $\begin{array}{c}0.5531 \\
(0.2370)\end{array}$ & $\begin{array}{l}-0.0095 \\
(0.1032)\end{array}$ & $\begin{array}{c}0.0174 \\
(0.7601)\end{array}$ & No \\
\hline (2) & $\begin{array}{c}0.6021 \\
(0.2428)\end{array}$ & $\begin{array}{l}-0.1393 \\
(0.1073)\end{array}$ & -- & Yes \\
\hline \multicolumn{5}{|l|}{ Medicaid: } \\
\hline (1) & $\begin{array}{c}1.1557 \\
(0.6551)\end{array}$ & $\begin{array}{l}-0.3268 \\
(0.5671)\end{array}$ & $\begin{array}{c}2.3941 \\
(0.9074)\end{array}$ & No \\
\hline (2) & $\begin{array}{c}0.7945 \\
(0.6544)\end{array}$ & $\begin{array}{c}0.1279 \\
(0.5439)\end{array}$ & -- & Yes \\
\hline \multicolumn{5}{|l|}{ Food stamps: } \\
\hline (1) & $\begin{array}{c}1.0830 \\
(0.3128)\end{array}$ & $\begin{array}{c}0.0810 \\
(0.2424)\end{array}$ & $\begin{array}{c}0.0178 \\
(0.9047)\end{array}$ & No \\
\hline (2) & $\begin{array}{c}0.8558 \\
(0.2637)\end{array}$ & $\begin{array}{c}0.1906 \\
(0.2052)\end{array}$ & --- & Yes \\
\hline \multirow{2}{*}{$\begin{array}{l}\text { Energy assistance: } \\
\text { (1) }\end{array}$} & & & & \\
\hline & $\begin{array}{c}1.0354 \\
(0.2445)\end{array}$ & $\begin{array}{c}0.0601 \\
(0.0450)\end{array}$ & $\begin{array}{c}0.2967 \\
(0.3832)\end{array}$ & No \\
\hline (2) & $\begin{array}{c}1.1819 \\
(0.2516)\end{array}$ & $\begin{array}{c}0.0387 \\
(0.0491)\end{array}$ & $\cdots$ & Yes \\
\hline (1) & $\begin{array}{c}0.6074 \\
(0.2477)\end{array}$ & $\begin{array}{l}-0.0175 \\
(0.1488)\end{array}$ & $\begin{array}{l}-0.0914 \\
(0.5630)\end{array}$ & No \\
\hline (2) & $\begin{array}{c}0.7735 \\
(0.2426)\end{array}$ & $\begin{array}{l}-0.0255 \\
(0.1439)\end{array}$ & -- & Yes \\
\hline $\begin{array}{l}\text { Breakfasts/unches: } \\
\text { (1) }\end{array}$ & $\begin{array}{c}0.0880 \\
(0.2421)\end{array}$ & $\begin{array}{c}0.4898 \\
(0.2239)\end{array}$ & $\begin{array}{l}-0.0423 \\
(0.9048)\end{array}$ & No \\
\hline (2) & $\begin{array}{l}-0.0395 \\
(0.1954) \\
\end{array}$ & $\begin{array}{r}0.5439 \\
(0.1814) \\
\end{array}$ & $\cdots$ & Yes \\
\hline
\end{tabular}

Notes: Standard errors are reported in parentheses. The regressions are estimated using a random effects estimator. The sample has 289 observations and is composed of immigrant households surveyed in the 1990/91 SIPP who migrated to the United States after 1985. The other explanatory variables included in the regression are: the number of persons in the household (by gender) who are under age 5 , under age 18, 18-34, 35-54, 55-64, 65 or over, the householder's age, education, gender, and race, and a dummy variable indicating if the household lives in one of the metropolitan areas identified in the SIPP file. 